\title{
Physiological role of the cellular prion protein
}

\author{
Viviana Zomosa-SignORET ${ }^{1}$, Jacques-Damien ARNAUD ${ }^{2}$, Pascaline FonTES $^{3}$, \\ Maria-Terresa ALVAREZ-MARTINEZ ${ }^{2}$, Jean-Pierre LIAUTARD ${ }^{1,2 *}$
}

\author{
${ }^{1}$ CPBS, UMR 5236, CC 100, Université Montpellier, 2 Place E. Bataillon, 34095 Montpellier Cedex, France \\ ${ }^{2}$ IFR-122, CC 100, Université Montpellier 2, Place E. Bataillon, 34095 Montpellier Cedex, France \\ ${ }^{3}$ CECEMA, Université Montpellier 2, Place E. Bataillon, 34095 Montpellier Cedex, France
}

(Received 10 May 2007; accepted 21 September 2007)

\begin{abstract}
The prion protein $(\mathrm{PrP})$ plays a key role in the pathogenesis of prion diseases. However, the normal function of the protein remains unclear. The cellular isoform $\left(\mathrm{PrP}^{C}\right)$ is expressed most abundantly in the brain, but has also been detected in other non-neuronal tissues as diverse as lymphoid cells, lung, heart, kidney, gastrointestinal tract, muscle, and mammary glands. Cell biological studies of PrP contribute to our understanding of $\operatorname{PrP}^{\mathrm{C}}$ function. Like other membrane proteins, $\operatorname{PrP}^{\mathrm{C}}$ is post-translationally processed in the endoplasmic reticulum and Golgi on its way to the cell surface after synthesis. Cell surface $\operatorname{PrP}^{\mathrm{C}}$ constitutively cycles between the plasma membrane and early endosomes via a clathrin-dependent mechanism, a pathway consistent with a suggested role for $\mathrm{PrP}^{\mathrm{C}}$ in cellular trafficking of copper ions. Although $\mathrm{PrP}^{-1-}$ mice have been reported to have only minor alterations in immune function, $\operatorname{PrP}^{\mathrm{C}}$ is up-regulated in $\mathrm{T}$ cell activation and may be expressed at higher levels by specialized classes of lymphocytes. Furthermore, antibody cross-linking of surface $\mathrm{PrP}^{\mathrm{C}}$ modulates $\mathrm{T}$ cell activation and leads to rearrangements of lipid raft constituents and increased phosphorylation of signaling proteins. These findings appear to indicate an important but, as yet, ill-defined role in T cell function. Recent work has suggested that $\operatorname{PrP}^{\mathrm{C}}$ is required for self-renewal of haematopoietic stem cells. $\mathrm{PrP}^{\mathrm{C}}$ is highly expressed in the central nervous system, and since this is the major site of prion pathology, most interest has focused on defining the role of $\operatorname{PrP}^{\mathrm{C}}$ in neurones. Although $\mathrm{PrP}^{-/-}$mice have a grossly normal neurological phenotype, even when neuronal $\operatorname{PrP}^{\mathrm{C}}$ is knocked out postnatally, they do have subtle abnormalities in synaptic transmission, hippocampal morphology, circadian rhythms, and cognition and seizure threshold. Other postulated neuronal roles for $\operatorname{Pr} \mathrm{P}^{\mathrm{C}}$ include copper-binding, as an anti- and conversely, pro-apoptotic protein, as a signaling molecule, and in supporting neuronal morphology and adhesion. The prion protein may also function as a metal binding protein such as copper, yielding cellular antioxidant capacity suggesting a role in the oxidative stress homeostasis. Finally, recent observations on the role of $\operatorname{PrP}^{\mathrm{C}}$ in long-term memory open a challenging field.
\end{abstract}

prion / $\operatorname{PrP}^{\mathrm{C}}$ / physiology / biology

Table of contents

1. Introduction

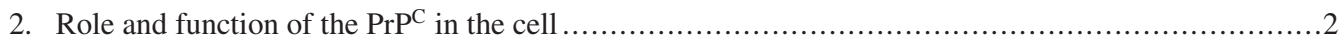

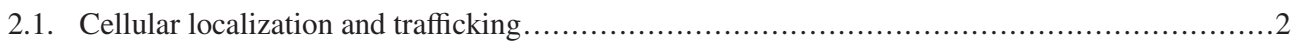

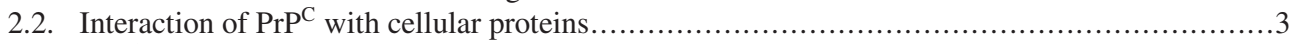

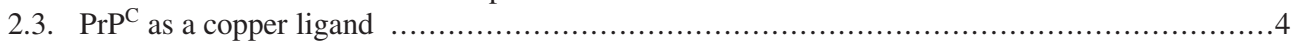

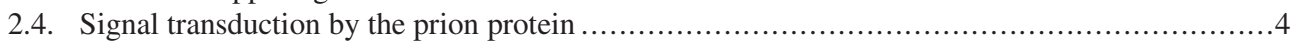

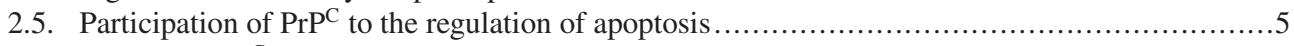

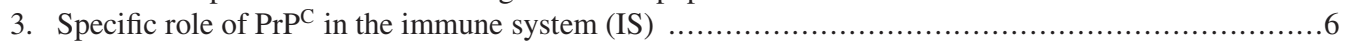

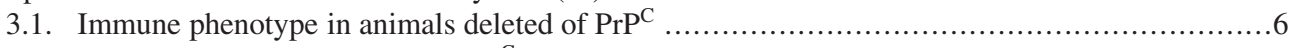

3.2. Distribution expression of the $\operatorname{PrP}^{\mathrm{C}}$ in the immune cells .......................................

* Corresponding author: liautard@univ-montp2.fr 


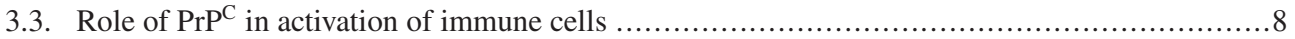

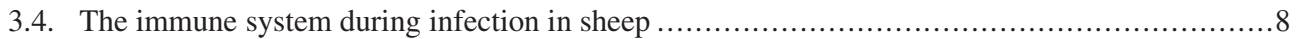

4. Specific role of the $\operatorname{PrP}^{\mathrm{C}}$ in the Central Nervous System (CNS) ......................................

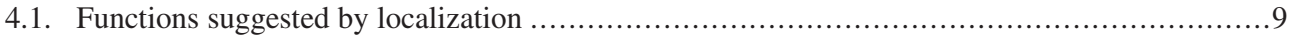

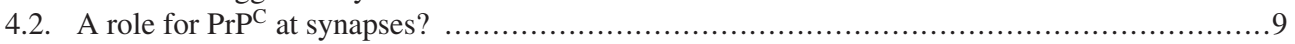

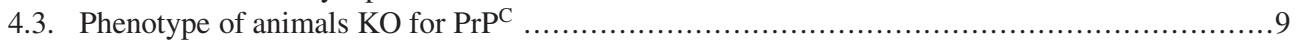

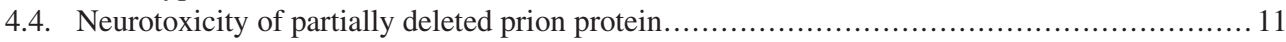

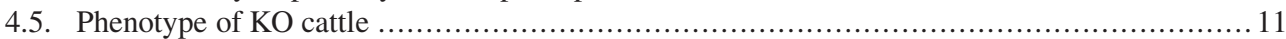

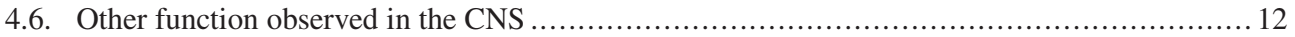

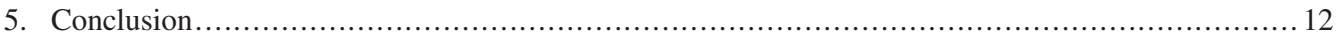

\section{INTRODUCTION}

Prion diseases are neurodegenerative disorders that affect animals and humans. In animals, the best known forms are scrapie in sheep and bovine spongiform encephalopathy in cattle, whereas the human variants include Creutzfeldt-Jakob disease, GerstmannStraussler-Scheinker disease, and fatal familial insomnia. The unique feature of these diseases is that, in addition to sporadic and inherited forms, they may be acquired by transmission of an infectious agent. According to the "protein-only" hypothesis, the infectious prion pathogen consists of an abnormal prion protein, $\operatorname{PrP}^{\mathrm{Sc}}$ [84]. This protein is an altered isoform of a normal cellular protein, $\mathrm{PrP}^{\mathrm{C}}$, which is host-encoded by a chromosomal gene and abundantly expressed in mammalian cells [85]. However, the two prion protein isoforms have profoundly different physical properties. $\operatorname{PrP}^{\mathrm{C}}$ exists as a monomer that is readily degradable by proteinase $\mathrm{K}$, whereas $\mathrm{PrP}^{\mathrm{Sc}}$ forms insoluble aggregates that show high resistance to proteinase $\mathrm{K}$ digestion and often have the characteristics of an amyloid [85]. The covalent structure of $\operatorname{PrP}^{\mathrm{Sc}}$ is most likely identical with that of $\operatorname{PrP}^{\mathrm{C}}$ [98]. $\mathrm{PrP}^{\mathrm{C}}$ is a 209-residue glycoprotein that has a single disulfide bridge, two N-glycosylation sites, and a glycosyl phosphatidyl inositol anchor [98]. It is localized in cholesterol-rich membrane microdomains called rafts or caveolaelike domains [106]. However, cytosolic localized PrP has also been detected [66]. Besides its conservation among species and expression in most tissues, the role of the cellular prion protein is not completely understood [63]. $\operatorname{PrP}^{\mathrm{C}}$ is expressed most abundantly in the brain, but has also been detected in other non-neuronal tissues as diverse as lymphoid cells, lung, heart, kidney, gastrointestinal tract, muscle, and mammary glands [43]. In the last few years, some possible biological functions for the cellular prion protein have been described. It has been postulated that $\mathrm{PrP}^{\mathrm{C}}$ may be involved in one or more of the following: neurotransmitter metabolism, immune cell activation [17,64], cell adhesion, signal transduction, copper metabolism, antioxidant activity, or programmed cell death [46]. Writing a review of current knowledge of the role of $\mathrm{PrP}^{\mathrm{C}}$ as a cellular protein appears to be a rather delicate task.

\section{ROLE AND FUNCTION OF THE PRP ${ }^{\mathrm{C}}$ IN THE CELL}

\subsection{Cellular localization and trafficking}

Knowledge on cellular localization is essential to propose possible realistic functions to the $\operatorname{PrP}^{\mathrm{C}}$. A lot of papers have been published but a consensus emerges.

Most studies indicate that $\operatorname{PrP}^{\mathrm{C}}$ associates with multi-molecular membrane complexes, which mediate a variety of functions in distinct cellular compartments [51]. $\operatorname{PrP}^{\mathrm{C}}$ continuously cycles between the plasma membrane and endocytic compartments. This process is related to the availability of the protein at the cell surface, and involves internalization pathways that may be critical for $\operatorname{PrP}^{\mathrm{C}}$ physiological functions [72]. Trafficking of $\mathrm{PrP}^{\mathrm{C}}$ seems to be a complex cellular event and may involve more than one internalization mechanism. Results for $\operatorname{PrP}^{\mathrm{C}}$ trafficking showed that the molecule traffics through the Golgi complex, plasma membrane, early recycling 
endosomes, and that dynamin I, a GTPase involved in the scission of endocytic vesicles, participates in the initial steps of $\mathrm{PrP}^{\mathrm{C}}$ cycling. These observations indicate that traffic of $\mathrm{PrP}^{\mathrm{C}}$ is not determined predominantly by the GPI anchor and that, differently from other GPI-anchored proteins, $\operatorname{PrP}^{\mathrm{C}}$ is delivered to classic endosomes after internalization [58]. $\mathrm{PrP}^{\mathrm{C}}$ is enriched in caveolae-like (raft?) both at the transgolgi network and plasma membrane and in interconnecting chains of endocytic caveolae-like domains $[81,106]$. It is delivered via caveolae-like domains to the pericentriolar region and via non-classical, caveolaecontaining early endocytic structures to late endosomes/lysosomes, it seems to bypass the internalization pathway mediated by clathrincoated vesicles but this work was performed using PrP-transfected $\mathrm{CHO}$ [81]. The distinctive feature of this trafficking is, however, that, while still on the cell surface, $\operatorname{PrP}^{C}$ leaves its raft environment to cross the non-raft membrane and then enter coated pits, where it is endocytosed. Endocytosed $\mathrm{PrP}^{\mathrm{C}}$-containing caveolae are not directed to the ER and Golgi complex but return to the surface [102]. It can be concluded that cell surface $\mathrm{PrP}^{\mathrm{C}}$ constitutively cycles between the plasma membrane and early endosomes via a clathrin-dependent mechanism, a pathway consistent with a suggested role for $\mathrm{PrP}^{\mathrm{C}}$ in cellular trafficking of copper ions [40].

\subsection{Interaction of $\operatorname{PrP}^{\mathrm{C}}$ with cellular proteins}

Another approach to establish biological function in the cell is to identify protein partners. Indeed, $\mathrm{PrP}^{\mathrm{C}}$ interacts with various macromolecules at the cell membrane, in endocytic compartments and in the secretory pathway.

The human 37-kDa laminin receptor precursor interacts with the prion protein [87]. It is a transmembrane protein that mediates internalization of $\mathrm{PrP}^{\mathrm{C}}$ and directs the complex through clathrin coated pits [34]. The laminin receptor is able to mediate internalization of only $25 \%$ to $50 \%$ of the membrane-bound recombinant $\operatorname{PrP}^{\mathrm{C}}$, which is consistent with both the participation of other cell surface proteins, as well as other pathways of internalization.
Furthermore, $\operatorname{PrP}^{\mathrm{C}}$ has also been reported as a saturable, specific, high-affinity receptor for laminin [36]. The interaction between $\mathrm{PrP}^{\mathrm{C}}$ and laminin was related to rat memory consolidation [20]. In addition, $\operatorname{PrP}^{C} 173-192$ peptide and anti-PrP ${ }^{C}$ or anti-laminin antibodies also inhibited the activation of hipocampal cAMPdependent protein kinase A (PKA) and extracellular regulated kinases (ERK1/2), three kinases that mediate the up-regulation of signaling pathways needed for consolidation of inhibitory avoidance memory.

It has been demonstrated that $\operatorname{PrP}^{\mathrm{C}}$ may associate with the microtubular cytoskeleton and its major component, tubulin [38]. The effect of full-length human recombinant PrP on tubulin polymerization was measured, and it was demonstrated that $\operatorname{PrP}^{\mathrm{C}}$ induces rapid association of tubulin into oligomers thereby inhibiting microtubule formation. $\operatorname{PrP}^{\mathrm{C}}$ seems to limit the number of tubulin heterodimers available for polymerization into microtubules, most probably by engaging them in the formation of oligomers. $\operatorname{PrP}^{\mathrm{C}}$ acts as a tubulinsequestering protein [73].

Stress inducible protein 1 (STI1) is a specific $\operatorname{PrP}^{\mathrm{C}}$ ligand that promotes neuroprotection of retinal neurons. Biochemical approaches have demonstrated that $\mathrm{PrP}^{\mathrm{C}}$ interacts specifically to this co-chaperone [114]. PrP ${ }^{\mathrm{C}}$ binds to cellular STI1, and coimmunoprecipitation assays suggest that both proteins are associated in vivo. $\operatorname{PrP}^{\mathrm{C}}$ interacts with STI1 through its highly conserved and hydrophobic domain, amino acids 113-129 [62]. $\operatorname{PrP}^{\mathrm{C}}$ and STI1 interact in a high affinity manner with a $\mathrm{K}_{\mathrm{d}}$ of $10^{-7} \mathrm{M}$. Cell surface binding and pull-down experiments showed that $\mathrm{PrP}^{\mathrm{C}}$ and STI1 are highly expressed on the hippocampus and that their interaction induces neuritogenesis and neuroprotection in hippocampal neurons [56] (see above).

Many others ligands have been identified, using various approaches, as possibly interacting with $\operatorname{PrP}^{\mathrm{C}}$, among them : $\alpha \beta$-crystalline, $\mathrm{Na}^{+} / \mathrm{K}^{+}$-ATPase $\alpha 3$ subunit, CNPase, $\beta$-actin, $\alpha$-spectrin and creatine kinase- $\beta$, synapsin $\mathrm{Ib}$, the adaptator protein Grb2, and the prion interactor Pint1 [82]. It is, however, difficult to propose a specific role for such a number 
of possibilities. Indeed, $\operatorname{PrP}^{\mathrm{C}}$ is an inherently sticky protein and the meaning of the interaction with many intracellular proteins has to be questioned. A better knowledge of the physiological function is necessary. On the contrary, the activation of the non-receptor tyrosine kinase fyn, which is enriched in brain synaptosomes and has been implicated in long-term potentiation [37], could represent a cellular pathway through which $\mathrm{PrP}^{\mathrm{C}}$ influences synaptic function [67].

The prion protein is a complex entity, although numerous binding partners have been found for the protein, its function still remains unclear. Each portion of the protein may have its own functional properties.

\section{3. $\operatorname{PrP}^{\mathrm{C}}$ as a copper ligand}

It is well known that the prion protein binds copper in vivo [8]. The N-terminal domain of $\mathrm{PrP}^{\mathrm{C}}$ contains octapeptide repeat motifs encompassing five $\mathrm{Cu}^{2+}$ ion binding sites. There is increasing evidence to support a functional role for $\operatorname{PrP}^{\mathrm{C}}$ in copper metabolism and several groups have investigated the physiological meaning of this association [10]. $\mathrm{PrP}^{\mathrm{C}}$ may be a principal copper-binding protein in brain membrane fractions and controls the activity of other membrane-associated copper-binding proteins. Prion protein expression alters copper uptake into cells and enhances copper incorporation into superoxide dismutase (SOD). Furthermore, the prion protein itself can act as a SOD [9]. Analysis of PrP related copper uptake by cells suggests that the $K_{m}$ for PrP facilitated copper uptake is in the nanomolar range which would suggest and affinity of $10^{-9} \mathrm{M}$ or less placing copper binding by the prion protein in an acceptable range. However, after a thorough analysis of the binding parameters, Wells et al. [112] have acutely argued for a physiological binding of $\mathrm{Cu}^{2+}$ to $\mathrm{PrP}^{\mathrm{C}}$ in the brain only when concentration increases locally as for instance during depolarization.

Using mutants of $\mathrm{PrP}^{\mathrm{C}}$ that lack either the octapeptide repeats or the N-terminal polybasic region, and a construct with a transmembrane anchor; Taylor and Hooper [103] showed that copper binding to octapeptide repeats promotes dissociation of $\operatorname{PrP}^{\mathrm{C}}$ from lipid rafts, whereas the $\mathrm{N}$-terminal polybasic region mediates its interaction with a transmembrane adaptor protein that engages the clathrin endocytic machinery.

Cells deficient in $\mathrm{PrP}^{\mathrm{C}}$ are less viable in culture compared with cells expressing wildtype PrP and are more susceptible to oxidative damage and toxicity caused by agents such as copper and hydrogen peroxide. $\mathrm{PrP}^{\mathrm{C}}$ might play an important role in oxidative stress homeostasis, not only in the central nervous system, but also in other organs [52]. Recombinant chicken and mouse $\operatorname{PrP}^{\mathrm{C}}$, as well as $\operatorname{PrP}^{\mathrm{C}}$ immunoprecipitated from brain tissue had superoxide dismutase (SOD) activity. The results suggest that $\operatorname{PrP}^{\mathrm{C}}$ has an enzymatic function, dependent on copper incorporation, consistent with its cellular distribution and indicating its direct role in cellular resistance to oxidative stress [9]. Cleavage close to, or within the octarepeat region has been termed $\beta$-cleavage and appears to be mediated by reactive oxygen species (ROS); this cleavage is copper dependent [65]. $\beta$-cleavage of $\mathrm{PrP}^{\mathrm{C}}$ could be a critical step whereby $\operatorname{PrP}^{\mathrm{C}}$ protects cells against oxidative stress [108].

Reintroduction of PrP into $\mathrm{PrP}^{-/-}$cells, rescues cells from apoptosis, upregulates SOD activity, enhances superoxide anion elimination, and inhibits caspase-3/9 activation. On the contrary, N-terminally truncated $\operatorname{PrP}^{\mathrm{C}}$ enhanced apoptosis accompanied by potentiation of superoxide production and caspase-3/9 activation due to inhibition of SOD. $\mathrm{PrP}^{\mathrm{C}}$ protects $\mathrm{PrP}^{-/-}$cells from apoptosis via superoxideand caspase-3/9 dependent pathways by upregulating SOD activity [90]. These results raise the possibility that some factors, which interact with $\operatorname{PrP}^{\mathrm{C}}$, may mediate copper transfer from $\operatorname{PrP}^{C}$ to $\mathrm{Cu} / \mathrm{Zn}-\mathrm{SOD}$, and the existence of the octapeptide region of $\operatorname{PrP}^{\mathrm{C}}$ may be indispensable for copper transfer and regulation of SOD activity. STI1 is a candidate for involvement in such interaction with $\mathrm{PrP}^{\mathrm{C}}$.

\subsection{Signal transduction by the prion protein}

$\operatorname{PrP}^{\mathrm{C}}$ localization in lipid rafts, membrane microdomains enriched in sphingolipids and cholesterol, and the association with signal transduction mechanisms, indicate that PrP 
may participate in cell signaling pathways [82]. Many signal transduction patterns have been uncovered during $\operatorname{PrP}^{\mathrm{C}}$ function analysis.

Phosphatidylinositol 3-kinase (PI 3-kinase) is a protein kinase that plays a pivotal role in many cellular processes including cell survival and apoptosis. PI 3-kinase is known to be sensitive to redox signaling by superoxide and hydrogen peroxide and to be activated by copper ions. PI 3-kinase catalyzes the formation of D3-phosphorylated phosphoinositides, notably phosphatidylinositol 3,4,5-triphosphate $\left(\mathrm{PIP}_{3}\right) . \mathrm{PIP}_{3}$ has several downstream target molecules, in particular the serine/threonine protein kinase $\mathrm{B}$ (PKB or Akt). The PI 3-kinase/Akt pathway suppresses cell death by regulating bcl-2 family member activity and mitochondrial function [12]. Both mouse neuroblastoma N2a cells and immortalized murine hippocampal neuronal cell lines expressing wild-type $\operatorname{PrP}^{\mathrm{C}}$ had a significantly higher PI 3-kinase activity levels than their respective controls. PI 3-kinase activity was found to be elevated in brain lysates from wild-type mice, as compared to prion proteinknockout mice. Recruitment of PI 3-kinase by $\operatorname{PrP}^{\mathrm{C}}$ was shown to contribute to cellular survival toward oxidative stress by using 3-morpholinosydnonimine (SIN-1) and serum deprivation. Moreover, both PI 3-kinase activation and cytoprotection by $\operatorname{PrP}^{\mathrm{C}}$ appear to rely on copper binding to the $\mathrm{N}$-terminal octapeptide of $\operatorname{PrP}^{\mathrm{C}}$. So the interaction of copper with the N-terminal domain of $\operatorname{PrP}^{\mathrm{C}}$ could enable transduction of a signal to PI 3-kinase which, in turn, mediates downstream regulation of cell survival [105]. Due to its plasma membrane-localization, copper bound $\mathrm{PrP}^{\mathrm{C}}$ that can act as a sensor for extracellular stress and transmit signals to the intracellular milieu, the PI 3-kinase cascade having a crucial role in activating neuroprotective mechanisms.

A caveolin-dependent coupling of $\mathrm{PrP}^{\mathrm{C}}$ to the tyrosine kinase fyn was shown [68]. This coupling was evidenced using the murine $1 \mathrm{C} 11$ neuronal cell line. The $1 \mathrm{C} 11$ clones behave as a committed neuroepithelial progenitor that lack neuron-associated functions. On induction, nearly all 1C11 cells develop bipolar extensions, express neuronal markers, such as neurofilaments, N-CAM, $\gamma \gamma$-enolase, or synaptophysin, and convert into either $1 \mathrm{C} 11^{5-\mathrm{HT}}$ serotonergic or $1 \mathrm{C} 11^{\mathrm{NE}}$ noradrenergic cells. In the $1 \mathrm{C} 11$ progenitor and throughout differentiation, $\mathrm{PrP}^{\mathrm{C}}$, caveolin, and fyn are endogenously expressed [67]. Schneider et al. [93] investigated whether $\operatorname{PrP}^{\mathrm{C}}$ might be coupled with a ROS production pathway in the $1 \mathrm{C} 11$ neuronal differentiation model. They identified NADPH oxidase, a major ROS generator in cells, and extracellular regulated kinases 1/2 (ERK 1/2), two mitogen-activated protein kinases (MAPK) as target of the $\mathrm{PrP}^{\mathrm{C}}$ mediated signaling. Similar responses were observed in neuronal and non-neuronal cells. Moreover, in 1C11 fully differentiated neuronal cells only, an involvement of the fyn kinase in the control of the $\operatorname{PrP}^{\mathrm{C}}$-induced transduction cascade was established, in agreement with the idea of some specificity of $\mathrm{PrP}^{\mathrm{C}}$ signaling related to the expression of a complete serotonergic or noradrenergic phenotype. In fully differentiated $1 \mathrm{C} 11$ progenies, caveolin appears to be one of the protagonists involved in $\mathrm{PrP}^{\mathrm{C}}$-coupling to the tyrosine kinase fyn [68]. Some cell specificity of $\operatorname{PrP}^{\mathrm{C}}$ signaling may be related to the onset of a $\mathrm{PrP}^{\mathrm{C}}$-caveolinfyn complex. In these cells, the direct control of NADPH oxidase on $\mathrm{PrP}^{\mathrm{C}}$-induced ERK activation, within a single transduction pathway, may be accounted for by lack of a functional $\mathrm{PrP}^{\mathrm{C}}$-caveolin-fyn ternary complex. By mobilizing transduction cascades controlling the cellular redox state and the ERK1/2 kinases and by altering 5-HT receptor-mediated intracellular response, $\mathrm{PrP}^{\mathrm{C}}$ takes part in the homeostasis of serotonergic neuronal cells. These findings may have implications for future research aiming at understanding the fate of serotonergic neurons in prion diseases [69].

\subsection{Participation of $\operatorname{PrP}^{\mathrm{C}}$ to the regulation of apoptosis}

The mechanism by which $\operatorname{PrP}^{\mathrm{C}}$ contributes to prion-induced neurotoxicity is unclear. One hypothesis is that $\mathrm{PrP}^{\mathrm{C}}$ normally serves a neuroprotective function that is abolished or subverted by interaction with $\operatorname{PrP}^{\mathrm{Sc}}$ [39]. In fact, several recent experiments have uncovered a cytoprotective activity of $\operatorname{PrP}^{\mathrm{C}}$ [89]. 
PrP overexpression rescues cultured neurons, some mammalian cell lines, and yeasts from several kinds of death-inducing stimuli [49, $53,89]$. Limited similarity between the Bcl-2 homology domain $(\mathrm{BH} 2)$ of the $\mathrm{Bcl}-2$ protein family members and the octapeptide repeats in the $\mathrm{N}$-terminal region of PrP suggest that PrP plays a role in survival or cell death. The $\mathrm{BH} 2$ domain was shown to mediate $\mathrm{Bcl}-2$ interaction with Bax protein and also to be responsible for Bcl-2 protection against Bax-mediated cell death. Furthermore, the C-terminal end of $\mathrm{Bcl}-2$ protein interacts with $\mathrm{PrP}$ in a yeast twohybrid system $[47,48]$. Therefore, it is possible that PrP actually acts as a member of the Bcl-2 family. Effectively, $\operatorname{PrP}^{\mathrm{C}}$ protects against Bax-mediated neuronal apoptosis and potently inhibits Bax-induced cell death in human primary neurons. Deletion of four octapeptide repeats of $\operatorname{PrP}$ as well as familial D178N and T183A PrP mutations completely or partially suppress the neuroprotective effect of PrP [7]. The molecular target of PrP is unknown. PrP could directly interact with and inhibit Bax or indirectly signal Bax inhibition [89]. The presence of $\mathrm{PrP}$ in the cytosol indicates that a direct interaction is possible. However, $\mathrm{PrP}^{\mathrm{C}}$ interaction with STI1 induces neuroprotective signals that rescue cells from apoptosis [114]. STI1, whose interaction with $\operatorname{PrP}^{\mathrm{C}}$ mediates neuroprotection through a cAMP/PKA signaling pathway [114] could be the receptor. Moreover, endogenous PrP has been found to protect cultured neurons against oxidative stress, and brain tissue against ischemia, hypoxia, or trauma in vivo $[75,97]$. Nevertheless, how the putative neuroprotective activity of $\mathrm{PrP}^{\mathrm{C}}$ might be altered during prion diseases to produce a neurotoxic effect remains unknown.

On the contrary, PrP overexpression has been reported to increase the susceptibility to the apoptotic inducer, staurosporine $[76,77]$. PrP toxicity may be mediated through p53 in these cells [78]. These results are in contradiction with reports indicating that the absence of PrP sensitizes cells to apoptotic insults such as serum deprivation and oxidative stress. However, many explanations can be proposed to explain this discrepancy, all of them suppose that overexpression results in a pathological form of the protein [89].

\section{SPECIFIC ROLE OF PRP ${ }^{\mathrm{C}}$ IN THE IMMUNE SYSTEM (IS)}

The relationship between prions and the IS is complex. The lack of a clear immune response in prion disease is assumed to be due to tolerance to $\mathrm{PrP}^{\mathrm{Sc}}$. Further, the IS actually contributes to pathogenesis by amplifying prion "load" in lymphoid compartments thereby facilitating efficient neuroinvasion (reviewed in [1]). This process is dependent at least partly on expression of $\mathrm{PrP}^{\mathrm{C}}$ by immune cells and pathogenesis is related to IS integrity and functionality [11]. Despite these results, the role of $\mathrm{PrP}^{\mathrm{C}}$ in IS has been poorly understood.

\subsection{Immune phenotype in animals deleted of $\operatorname{PrP}^{\mathrm{C}}$}

$\operatorname{PrP}^{\mathrm{C}}$ knockout in mice has not allowed to easily conclude on a particular role of the protein in IS as in the first studies no significant differences have been found in the immunological phenotype (number of cells in the different organs, sub-population percentage in lymphoid tissues and blood), in comparison with wild-type animals [13]. However, more recent analyses of the immune system in $\mathrm{PrP}^{-/-}$mice reveal fine tuned regulations. $\mathrm{PrP}^{\mathrm{C}}$ is expressed on the surface of longterm (LT) haematopoietic stem cells (HSC) and HSC from $\mathrm{PrP}^{-/-}$mice exhibited impaired self-renewal in serial transplantation of lethally irradiated mouse recipients both in the presence and absence of competitors. Furthermore, when treated with a cell cycle-specific myelotoxic agent, the animals reconstituted with $\mathrm{PrP}^{-/-}$HSC exhibit increased sensitivity to haematopoietic cell depletion. It can be concluded that $\operatorname{PrP}^{\mathrm{C}}$ supports self-renewal HSC [115]. The same kind of finding has been done on neurons (see below). Besides this role in the development of the immune system, some results suggest a complex role in the function of the immune system. Comparison of lectininduced mitogenesis and selected cell signaling pathways in splenocytes from wild-type $\mathrm{BALB} / \mathrm{c}$ and $\mathrm{PrP}^{-/-}$mice has revealed that activation was significantly reduced in $\mathrm{PrP}^{-/-}$ 
splenocytes, most prominently early in activation [64]. Activation in $\mathrm{PrP}^{-/-}$splenocytes is associated with differences in the phosphorylation patterns of protein kinase $\mathrm{C}$ and ERK1/2. However, phosphorylation profiles are similar in wild-type and $\mathrm{PrP}^{-/-}$splenocytes following PMA treatment, indicating that the ability of these two enzymes to be phosphorylated is not impaired in the absence of $\mathrm{PrP}^{\mathrm{C}}$. The calcium induced fluxes are equivalent in $\mathrm{PrP}^{-/-}$and $\mathrm{PrP}^{+/+}$splenocytes, suggesting that calcium-dependent mechanisms are not directly implicated in the differential phosphorylation patterns or mitogenic responses. $\mathrm{PrP}^{-/-}$splenocytes display defects in upstream or downstream mechanism(s) that modulate PKC phosphorylation, which in turn affects its capacity to regulate splenocyte mitosis, consistent with a role for $\mathrm{PrP}^{\mathrm{C}}$ in immune function [64].

Based on work in $\mathrm{PrP}^{-/-}$mice or cells derived from them, $\mathrm{PrP}^{\mathrm{C}}$ has been proposed to down-regulate phagocytosis by macrophages [26] but also to be involved in the phagocytic machinery used by Brucella abortus to invade macrophages [107], although this finding has been clearly challenged [31].

\subsection{Distribution expression of the $\operatorname{PrP}^{\mathrm{C}}$ in the immune cells}

Clues to the function of $\operatorname{PrP}^{\mathrm{C}}$ may be gleaned by examination of cell-specific expression patterns. CD34+ haematopoietic stem cells express $\operatorname{PrP}^{\mathrm{C}}$, but, although lymphocytes and monocytes at least maintain $\operatorname{PrP}^{\mathrm{C}}$ expression throughout their differentiation, $\mathrm{PrP}^{\mathrm{C}}$ is downregulated upon differentiation along the granulocyte lineage [27]. In contrast, maturation of monocytes and dendritic cells (DC) leads to $\mathrm{PrP}^{\mathrm{C}}$ up-regulation [15]. DC display the highest expression levels of $\operatorname{PrP}^{\mathrm{C}}$, in both humans and mice $[15,54] . \operatorname{PrP}^{\mathrm{C}}$ was found to be present on murine epidermis Langerhans cells [101], on DC in extrafollicular areas, including T cell zones, of the gut mucosa [32], and DC of the splenic white pulp [15]. $\mathrm{PrP}^{\mathrm{C}}$ was found on the surface of bone marrowderived human and mouse DC generated in vitro in the presence of GMCSF, at levels that increased with LPS stimulation and cor- related with that of MHC II and costimulatory molecule CD86 $[3,15]$. Higher $\operatorname{PrP}^{\mathrm{C}}$ levels were found on the surface of spleen DC that are also CD8 $\alpha+$; expression of this marker has been correlated with the secretion of IL-12 and IFN- $\alpha$ [61]. In lymph nodes, the highest $\mathrm{PrP}^{\mathrm{C}}$ level was observed in the CD8int subset, which are strong stimulators of Ag-dependent delayed-type hypersensitivity. This was interpreted as a possible involvement of $\mathrm{PrP}^{\mathrm{C}}$ in $\mathrm{T}$ cell activation leading to Th1 responses [61]. However, the mechanisms involved in $\mathrm{T}$ cell activation related to $\mathrm{PrP}^{\mathrm{C}}$ expressed on $\mathrm{DC}$ remain to be explored.

Studies in mice show a trend towards downregulation of $\mathrm{PrP}^{\mathrm{C}}$ with $\mathrm{B}$ and $\mathrm{T}$ cell maturation, and mature $\mathrm{T}$ lymphocyte expression during quiescence is low [55]. However, in humans and sheep $\mathrm{PrP}^{\mathrm{C}}$ expression on mature blood and lymphoid cells remains high [54], with levels increasing further with ageing [83]. This discrepancy between mice and humans suggests that the results should be interpreted cautiously.

In mature immune cells, $\operatorname{PrP}^{C}$ has been detected on human $\mathrm{T}$ and $\mathrm{B}$ lymphocytes, natural killer (NK) cells, platelets, monocytes, dendritic cells, and follicular dendritic cells [2, 4, 15, 54, 55, 83]. CD8+ cells express slightly more $\operatorname{PrP}^{\mathrm{C}}$ than $\mathrm{CD} 4+$ cells and $\mathrm{PrP}^{\mathrm{C}}$ expression may be somewhat higher in peripheral blood T cells than in B lymphocytes [83]. $\mathrm{PrP}^{\mathrm{C}}$ expression is also higher in $\mathrm{CD} 45 \mathrm{RO}+$ memory compared to CD45RA+ naive T lymphocytes $[28,54]$. Furthermore, $\operatorname{PrP}^{\mathrm{C}}$ expression increases during human NK cell differentiation, with particularly high levels on CD56+ CD3+ NK cells [28].

Gene expression microarrays have revealed murine Prnp to be up-regulated in certain types of T cell, via a Stat6-dependent mechanism after interleukin IL-4 treatment [18].

$\operatorname{PrP}^{\mathrm{C}}$ expression by immune cells has been rarely studied in other mammalian species, probably because humans and mice are the better studied models of TSE pathogenesis. In the hamster, however, $\operatorname{PrP}^{\mathrm{C}}$ has been observed, in very weak quantities on the diverse peripheral blood cell sub-populations [42]. 


\subsection{Role of $\operatorname{PrP}^{C}$ in activation of immune cells}

In regards to the necessity of the cellular prion protein expression for TSE pathogenesis, particularly during replication and multiplication phases of the infectious agent in secondary lymphoid organs, the role of $\mathrm{PrP}^{\mathrm{C}}$ has been investigated in the different cells constituting immune tissues. In these cells, two main functions of $\operatorname{PrP}^{\mathrm{C}}$ have been demonstrated: as a membrane receptor, and as a signaling molecule.

Despite the absence of evidence of a participation of $\mathrm{T}$ lymphocytes in TSE pathogenesis, studies on the immune role of $\mathrm{PrP}^{\mathrm{C}}$ have focused on this cell sub-population after the results of Cashman et al. [17]. They first observed an up-regulation of $\operatorname{PrP}^{\mathrm{C}}$ during mitogenic activation of human $\mathrm{T}$ cells isolated from peripheral blood as well as an implication of $\mathrm{PrP}^{\mathrm{C}}$ crosslink by specific antibodies in the regulation of mitogenic activation of these cells. From this time, this result has been confirmed by others, nevertheless, no more investigations have been done in this way and the finding of such a role for the prion protein in mitogenic activation of $\mathrm{T}$ cells remained evasive [54].

In the absence of a natural ligand for $\operatorname{PrP}^{\mathrm{C}}$, spatial rapprochement of the membrane proteins by specific antibodies is currently used to mimic the "physiological" engagement of the prion protein. Due to its membrane localization, this subterfuge has been used with the aim to demonstrate a potential role of $\operatorname{PrP}^{\mathrm{C}}$ as a membrane receptor. Crosslink of $\operatorname{PrP}^{\mathrm{C}}$ on the surface of $\mathrm{T}$ cell lines has been associated with various cellular responses like intracellular calcium mobilization, Src and Erk kinase activation or capping of lipidic microdomains in a large membrane zone where $\operatorname{PrP}^{\mathrm{C}}$ colocalize with Thy-1 or fyn kinase $[44,100]$. The contribution of $\mathrm{PrP}^{\mathrm{C}}$ to the classical T-lymphocyte activation process has been characterized by clustering the T-cell receptor component CD3ع as well as PrP with soluble and surfaceimmobilized antibodies, respectively. $\operatorname{PrP}^{\mathrm{C}}$ is a component of signaling structures recently described as plasma membrane microclusters established during T-lymphocyte activation. The formation of immunological synapses, however, did not depend on the presence of $\mathrm{PrP}^{\mathrm{C}}$ as proven by siRNA knockdown experiments, indicating a fine physiological role of PrP in vivo within the immune system [74]. These findings underscore a very subtle role of PrP during the process of human $\mathrm{T}$ lymphocyte activation. Although PrP seems to be dispensable during TCR-dependent induction of immune synapse formation, stimulation of cells with surface-immobilized anti-PrP antibodies resulted in the induction of complex $\mathrm{Ca}^{2+}$ signaling patterns. While the amplitude of these signals resembles the $\mathrm{Ca}^{2+}$ pulses obtained during TCR stimulation, the frequency as well as the pattern and the duration of these traces differed profoundly. Thus cross-linking of $\operatorname{PrP}^{\mathrm{C}}$ with surface-immobilized antibodies is sufficient to initiate several different signaling cascades. $\mathrm{PrP}^{\mathrm{C}}$ is very likely a component of signaling membrane microdomains. Furthermore, $\operatorname{PrP}^{\mathrm{C}}$ has obvious in vivo consequences during the activation of the immune system by regulating the ability of APC to stimulate proliferative T-cell responses [3]. A modulating function of $\operatorname{PrP}^{\mathrm{C}}$ during the fine tuning of the lymphocyte activation process is therefore very conceivable.

\subsection{The immune system during infection in sheep}

Significant differences in immune cell subsets and PrP expression occur between ARQ/ARQ and ARR/ARR Suffolk sheep in the preclinical phase of scrapie infection. Following challenge, significantly more CD8(+) and gamma-delta(+) $\mathrm{T}$ cells were detected in the PBMC of resistant sheep. However, CD21(+) cell expression was significantly higher in the lymph nodes of susceptible sheep. In contrast, more CD4(+) cells were detected in lymph nodes of resistant sheep at both time points [29].

\section{SPECIFIC ROLE OF THE PRP ${ }^{\mathrm{C}}$ IN THE CENTRAL NERVOUS SYSTEM (CNS)}

$\operatorname{PrP}^{\mathrm{C}}$ is highly expressed in CNS, and since this is the major site of prion pathology most interest has focused on defining the role of $\mathrm{PrP}^{\mathrm{C}}$ in neurons. 


\subsection{Functions suggested by localization}

The localization of $\operatorname{PrP}^{\mathrm{C}}$ within the CNS is a key step to know the potential structures liable to be affected by the scrapie agent. Moreover, the study of the chemical nature of the $\mathrm{PrP}^{\mathrm{C}}$-containing neurons is fundamental to understand both the biology of $\operatorname{PrP}^{\mathrm{C}}$ in vivo and the pathophysiology of $\mathrm{PrP}^{\mathrm{Sc}}$.

The fact that the protein is expressed in neurons at higher levels than in any other cell type suggests that $\operatorname{PrP}^{\mathrm{C}}$ has special importance in neurons. Additionally, $\mathrm{PrP}^{\mathrm{C}}$ is highly concentrated at the synapse [5] and there is evidence for intense localization not only at CNS synapses but also at endplates [33]. Furthermore $\operatorname{PrP}^{\mathrm{C}}$ expression has been shown both presynaptically and postsynaptically $[41,91]$. Evidence exists for specific axonal transport of different $\mathrm{PrP}^{\mathrm{C}}$ glycoforms suggesting that perhaps one glycoform or another might be specifically presynaptic [88]. $\mathrm{PrP}^{\mathrm{C}}$ can be isolated in detergent insoluble rafts, and there is evidence that such rafts might represent specialized areas of synaptic membrane that might in turn give rise to cavaeolae-like domains. The full details of the specialized association of $\operatorname{PrP}^{\mathrm{C}}$ with the synaptic membrane have not yet emerged but it is probable that two forms of $\mathrm{PrP}^{\mathrm{C}}$ exist in neurons: synaptic and non-synaptic.

Cellular prion protein is present in all cortico-cerebellar and deep nuclei neuronal cell types, as well as in all glial cell types of the rat cerebellum [50]. The protein is exclusively located on the outer cell membrane and in Golgi and endosomal intracytoplasmic organelles, with no cytoplasmic or synaptic vesicle labeling. Most importantly, the cellular prion protein is distributed on all portions of neurons, without any preferential synaptic targeting. The ubiquitous presence would support the notion that the prion protein has a generalized cellular function in brain tissue rather than a specialized role restricted to synaptic transmission. However, the labeling of glial cells is challenged by the careful study of Ford et al. [32].

\subsection{A role for $\operatorname{PrP}^{\mathrm{C}}$ at synapses?}

Several experimental observations suggest that $\mathrm{PrP}^{\mathrm{C}}$ could play a role in synaptic struc- ture, function or maintenance. Light and electron microscopic studies indicate that $\operatorname{PrP}^{\mathrm{C}}$ is preferentially concentrated along axons and in presynaptic terminals $[66,70]$. In addition, $\mathrm{PrP}^{\mathrm{C}}$ is subject to anterograde and retrograde axonal transport $[6,71]$. Incubation of cultured hippocampal neurons with recombinant $\mathrm{PrP}$ induces rapid elaboration of axons and dendrites, and increases the number of synaptic contacts [45]. This result suggests that $\mathrm{PrP}^{\mathrm{C}}$ could play a regulatory role in synapse formation. Electrophysiological recordings from brain slices of $\mathrm{PrP}^{-/-}$mice also support a functional role for $\mathrm{PrP}^{\mathrm{C}}$ in synaptic transmission. It has been reported, in hippocampal slices from $\mathrm{PrP}^{-/-}$mice, that long term potentiation was impaired [23]. $\mathrm{PrP}^{-/-}$mice have been reported to display several other neurobiological abnormalities that may also relate to the participation of $\mathrm{PrP}^{\mathrm{C}}$ in synapse formation and function. These include alterations in nerve fiber organization [22], circadian rhythm [104], and spatial learning [24]. Conditional PrP knockout mice have shown that significant reduction of after hyperpolarization potentials in hippocampal cells was observed, suggesting a direct role for PrP in the modulation of neuronal excitability. These data provide new insight into PrP functions. Furthermore, studies have demonstrated a positive correlation between the expression level of $\operatorname{PrP}^{\mathrm{C}}$ and the overall strength of glutamatergic transmission in the hippocampus, with PrP-over-expressing mice exhibiting supra-physiological responses [16]. At least part of this effect seems to result from more efficient recruitment of presynaptic fibers as the level of $\operatorname{PrP}^{\mathrm{C}}$ increases, correlating with reduced after-hyperpolarization seen in hippocampal CA1 neurons of $\mathrm{PrP}^{-/-}$mice [22]. Reduced after-hyperpolarization was observed in pyramidal neurons regardless of whether the PrP gene was deleted pre- or postnatally [59]. All these data are strong evidence for a functional role for $\operatorname{PrP}^{\mathrm{C}}$ in modulating synaptic transmission.

\subsection{Phenotype of animals $\mathrm{KO}$ for $\operatorname{PrP}^{\mathrm{C}}$}

Attempts to deduce the function of $\mathrm{PrP}^{\mathrm{C}}$ from the phenotypes of PrP-null mice had been long time unrewarding, since the lines of 
these mice in which the adjacent Doppel (Dpl) gene is not artifactually upregulated display no major anatomical or developmental deficits $[13,60]$, but the mice are resistant to scrapie infection [14].

Nevertheless, recent findings show that mice devoid of the PrP gene present fine morphologic or phenotypic alterations. The PrP gene seems to play a role in sleep and in the circadian rhythms [104]. One must bear in mind that one of the inherited prion diseases consists of a profound alteration in sleep and the daily rhythms of many hormones [92].

Morphologic alterations have also been detected. Stained hippocampal sections from the $\mathrm{PrP}^{-/-}$mice had more granules than the wild type in the following: the granule cell layer, the inner molecular layer of the dentate gyrus, and the infrapyramidal region [22]. This resembles the mossy fibre collateral and terminal sprouting seen in certain epilepsies. The abnormal connectivity might be predicted to promote epileptiform activity, but extracellular electrophysiological recordings from the granule cell layer reveals a reduced excitability in the PrPnull group, both with and without blockade of GABA receptor-mediated inhibition. It was proposed that reorganization of neuronal circuitry is a feature of $\mathrm{PrP}^{-/-}$mice [22].

In one study [109, 110], infarct volumes were measured in wild-type and $\mathrm{PrP}^{-/-}$mice that had been subjected to focal cerebral ischemia. It was found that $\mathrm{PrP}^{-/-}$mice displayed significantly larger infarct volumes, demonstrating a protective role for $\mathrm{PrP}^{\mathrm{C}}$ in response to brain injury.

Furthermore, it was demonstrated later on the Zurich $\mathrm{PrP}^{-/-}$mice [13] that they develop an age-dependent impairment in memory consolidation which only becomes detectable in animals that are at least nine months old [19]. Criado et al. [24] observed that a second strain of $\mathrm{PrP}^{-/-}$(the Npu mouse strain [60]), in either a pure 129/Ola background or a mixed 129/Ola $\times$ C57-B1/10 background exhibited impaired hippocampal dependent spatial learning, while non-spatial learning remained intact. These deficits are rescued when $\mathrm{PrP}^{\mathrm{C}}$ is selectively re-expressed in neurons, indicating that they are caused by $\operatorname{PrP}^{\mathrm{C}}$ loss-of- function in neurons [24]. In addition, as mentioned above, post-natal $\mathrm{PrP}^{-/-}$mice exhibit reduced after-hyperpolarization potentials in hippocampal cells, a finding that suggests that $\operatorname{PrP}^{\mathrm{C}}$ may directly modulate neuronal excitability [59]. Furthermore, we have seen in the first chapter that STI1 is a specific $\operatorname{PrP}^{\mathrm{C}}$ ligand that promotes neuroprotection of retinal neurons through cAMP-dependent protein kinase A [114]. Both $\operatorname{PrP}^{\mathrm{C}}$ and STI1 are abundantly expressed and highly colocalized in the hippocampus in situ, indicating that they can interact in vivo. Recombinant STI1 added to hippocampal cultures interacts with $\mathrm{PrP}^{\mathrm{C}}$ at the neuronal surface and elicits neuritogenesis in wild-type neurons but not in $\operatorname{PrP}^{\mathrm{C}}$-null cells. This effect is abolished by antibodies against either $\operatorname{PrP}^{\mathrm{C}}$ or STI1 and is dependent on the STI1 domain that binds $\mathrm{PrP}^{\mathrm{C}}$ [56]. Binding of these proteins induced the phosphorylation/activation of the mitogen activated protein kinase, which is essential for STI1-promoted neuritogenesis. STI1, but not its counterpart lacking the $\operatorname{PrP}^{\mathrm{C}}$ binding site, prevents cell death via PKA activation. These results demonstrate that two parallel effects of the PrP $\mathrm{P}^{\mathrm{C}}$-STI1 interaction, neuritogenesis and neuroprotection, are mediated by distinct signaling pathways [56]. Furthermore, STI1 interaction with $\mathrm{PrP}^{\mathrm{C}}$ affects short-term memory (STM) formation and long-term memory (LTM) consolidation [21]. Blockage of $\mathrm{PrP}^{\mathrm{C}_{-}}$ STI1 interaction with intra-hippocampal infusion of antibodies against $\mathrm{PrP}^{\mathrm{C}}$ or STI1 immediately after training impaired both STM and LTM. Furthermore, infusion of $\mathrm{PrP}^{\mathrm{C}}$ peptide 106-126, which competes for $\operatorname{PrP}^{\mathrm{C}}$-STI1 interaction, also inhibited both forms of memory. Remarkably, STI1 peptide 230-245, which includes the $\operatorname{PrP}^{C}$ binding site, had a potent enhancing effect on memory performance, which could be blocked by co-treatment with the competitive $\mathrm{PrP}^{\mathrm{C}}$ peptide 106-126. These results demonstrate that $\mathrm{PrP}^{\mathrm{C}}$-STI1 interaction modulates both STM and LTM [21]. Since $\mathrm{PrP}^{\mathrm{C}}$ interactions seem to be essential to many biological phenomena related to cell signaling, neural plasticity and memory consolidation, it is not surprising that alterations in this protein should affect cognitive processes. Indeed, 
recent reports in humans indicate that $\mathrm{PrP}^{\mathrm{C}}$ polymorphisms at codon 129 , a site that is highly important for the protein structure [80, 94], affect cognition and LTM [79].

The diversity of phenotypes in $\mathrm{PrP}^{-/-}$mice suggests either that $\mathrm{PrP}^{\mathrm{C}}$ plays a widespread role in the normal function of membrane proteins, or that it affects events earlier in development, having a wide variety of non-lethal consequences. This noticing is corroborated by recent works on the role of $\operatorname{PrP}^{\mathrm{C}}$ on the proliferation of neurons during development. Indeed, in vivo and in vitro studies have found that $\mathrm{PrP}^{\mathrm{C}}$ is expressed in multipotent neural precursors and mature neurons. Loss and gainof-function experiments demonstrate that $\mathrm{PrP}^{\mathrm{C}}$ levels correlate with differentiation of multipotent neural precursors into mature neurons in vitro and that $\mathrm{PrP}^{\mathrm{C}}$ levels positively influence neuronal differentiation in a dose-dependent manner. $\mathrm{PrP}^{\mathrm{C}}$ also increases cellular proliferation in vivo. $\operatorname{PrP}^{\mathrm{C}}$ overexpresser mice have more proliferating cells compared with wildtype or $\mathrm{PrP}^{-/-}$mice implying that $\mathrm{PrP}^{\mathrm{C}}$ plays an important role in neurogenesis and differentiation. However, because the final number of neurons produced is unchanged by $\operatorname{PrP}^{\mathrm{C}}$ expression, other factors must control the ultimate fate of new neurons [99].

\subsection{Neurotoxicity of partially deleted prion protein}

Various PrP mutations have given rise to pathological phenotypes when overexpressed in mice. For example, $\mathrm{PrP}^{-/-}$mice expressing $\operatorname{PrP}$ with deletions of the amino acid 121 or 134 develop severe ataxia and apoptosis of the cerebellar granule cell layer as early as 1-3 months of age [95]. Neurons in the cortex and elsewhere express truncated PrP at similar levels as granule cells but do not undergo cell death, arguing against an unspecific toxic effect [111]. The pathological phenotype is completely abolished by the introduction of a single wild-type Prnp allele. When the truncated $\operatorname{PrP}$ is specifically targeted to Purkinje cells of $\mathrm{PrP}^{-/-}$mice, ataxia and Purkinje cell degeneration develop, while the cerebellar granule layer remains unaffected [30]. Mice expressing PrP with the octare- peats $(\operatorname{PrP} \Delta 23-88)$ deleted or even, in addition, lacking $\alpha$-helix- 1 and $\beta$-sheet-2 ( $\Delta 141-$ 176, "PrP106") remained healthy. Wild-type mice transgenic for murine PrP23-230, which promotes accumulation of cytosolic PrP, develop severe ataxia, with cerebellar degeneration and gliosis [57] although it is not the case in culture cells [25]. The mice expressing a PrP $\Delta 105-125$ spontaneously developed a severe neurodegenerative illness that is lethal within one week of birth in the absence of endogenous PrP [113]. This phenotype was reversed in a dose-dependent fashion by coexpression of wild-type PrP. This phenotype is reminiscent of those described in mice that express PrP harboring larger deletions.

The results have been explained by a model in which truncated $\mathrm{PrP}^{\mathrm{C}}$ acts as dominant negative inhibitor of a functional homologue of $\mathrm{PrP}^{\mathrm{C}}$, with both competing for the same putative $\mathrm{PrP}^{\mathrm{C}}$ ligand [95].

\subsection{Phenotype of KO cattle}

The ability to genetically engineer animals has become a standard laboratory tool for physiological, genetic, and biomedical research. However, mice represent the vast majority of transgenic animals produced to date. Additional animal models are also of critical importance for physiological and medical research because mice are not completely representative of livestock animals or human physiology. For example, the limited life span and small size of the mouse restrict its usefulness in studies requiring long-term evaluation of test subjects. Thus PrP knockout in animals naturally subject to prion disease represents a very interesting approach for the elucidation of $\mathrm{PrP}^{\mathrm{C}}$ function and prion pathogenesis. In 2006, suppression of the prion protein in the goat thanks to RNA interference have been realised by Golding et al. [35] but the phenotype is not yet published. However, recently, generation of $\mathrm{PrP}^{-/-}$cattle has been made [86] by a sequential gene-targeting system. $\mathrm{PrP}^{-/-}$cattle do not present obvious abnormalities from birth to 20 months of age confirming in some ways the results obtained with mice. We do not yet know if the $\mathrm{PrP}^{-/-}$cattle is resistant to the prion. 


\subsection{Other function observed in the CNS}

Cross-linking of $\mathrm{PrP}^{\mathrm{C}}$ in vivo with specific monoclonal antibodies was found to trigger rapid and extensive apoptosis in hippocampal and cerebellar neurons. These findings suggest that $\operatorname{PrP}^{\mathrm{C}}$ functions in the control of neuronal survival and provides a model to explore whether cross-linking of $\mathrm{PrP}^{\mathrm{C}}$ by oligomeric $\mathrm{PrP}^{\mathrm{Sc}}$ can promote neuronal loss during prion infection [96].

\section{CONCLUSION}

Understanding the normal function of $\operatorname{PrP}^{\mathrm{C}}$ has important implications for the therapy of prion disorders. At present, most therapeutic strategies are directed at inhibiting the formation of $\mathrm{PrP}^{\mathrm{Sc}}$. If alterations in $\mathrm{PrP}^{\mathrm{C}}$ function play an important role in prion-induced pathology, then an alternative approach is to target the cellular pathways mediating the biological actions of $\mathrm{PrP}^{\mathrm{C}}$. In this regard, it might be possible to use the physiological activity of $\operatorname{PrP}^{\mathrm{C}}$ to develop in vitro assays to screen for drugs that have therapeutic potential. In addition, if the toxicity of $\mathrm{PrP}^{\mathrm{Sc}}$ is partly attributable to a loss of PrP function, then over-expression of wild-type PrP may represent a strategy for suppressing the disease phenotype. Conversely, reduction of PrP expression, a strategy that has been proposed for preventing or treating prion diseases, may have detrimental consequences due to loss of the neuroprotective activity of $\operatorname{PrP}^{\mathrm{C}}$ [113].

Acknowledgements. This work was supported by grant FP6-023144 from the European Union.

\section{REFERENCES}

[1] Aguzzi A., Prions and the immune system: a journey through gut, spleen, and nerves, Adv. Immunol. (2003) 81:123-171.

[2] Antoine N., Cesbron J.Y., Coumans B., Jolois O., Zorzi W., Heinen E., Differential expression of cellular prion protein on human blood and tonsil lymphocytes, Haematologica (2000) 85:475-480.

[3] Ballerini C., Gourdain P., Bachy V., Blanchard N., Levavasseur E., Gregoire S., Fontes P., Aucouturier P., Hivroz C., Carnaud C., Functional implication of cellular prion protein in antigen-driven interactions between T cells and dendritic cells, J. Immunol. (2006) 176:7254-7262.
[4] Barclay G.R., Hope J., Birkett C.R., Turner M.L., Distribution of cell-associated prion protein in normal adult blood determined by flow cytometry, Br. J. Haematol. (1999) 107:804-814.

[5] Barmada S., Piccardo P., Yamaguchi K., Ghetti B., Harris D.A., GFP-tagged prion protein is correctly localized and functionally active in the brains of transgenic mice, Neurobiol. Dis. (2004) 16:527-537.

[6] Borchelt D.R., Koliatsos V.E., Guarnieri M., Pardo C.A., Sisodia S.S., Price D.L., Rapid anterograde axonal transport of the cellular prion glycoprotein in the peripheral and central nervous systems, J. Biol. Chem. (1994) 269:14711-14714.

[7] Bounhar Y., Zhang Y., Goodyer C.G., LeBlanc A., Prion protein protects human neurons against Baxmediated apoptosis, J. Biol. Chem. (2001) 276:3914539149.

[8] Brown D.R., Qin K., Herms J.W., Madlung A., Manson J., Strome R., Fraser P.E., Kruck T., von Bohlen A., Schulz-Schaeffer W., Giese A., Westaway D., Kretzschmar H., The cellular prion protein binds copper in vivo, Nature (1997) 390:684-687.

[9] Brown D.R., Wong B.S., Hafiz F., Clive C., Haswell S.J., Jones I.M., Normal prion protein has an activity like that of superoxide dismutase, Biochem. J. (1999) 344:1-5.

[10] Brown D.R., Copper and prion disease, Brain Res. Bull. (2001) 55:165-173.

[11] Brown K.L., Stewart K., Ritchie D.L., Mabbott N.A., Williams A., Fraser H., Morrison W.I., Bruce M.E., Scrapie replication in lymphoid tissues depends on prion protein-expressing follicular dendritic cells, Nat. Med. (1999) 5:1308-1312.

[12] Brunet A., Datta S.R., Greenberg M.E., Transcription-dependent and -independent control of neuronal survival by the PI3K-Akt signaling pathway, Curr. Opin. Neurobiol. (2001) 11:297-305.

[13] Bueler H., Fischer M., Lang Y., Bluethmann H., Lipp H.P., DeArmond S.J., Prusiner S.B., Aguet M., Weissmann C., Normal development and behaviour of mice lacking the neuronal cell-surface PrP protein, Nature (1992) 356:577-582.

[14] Bueler H., Aguzzi A., Sailer A., Greiner R.A., Autenried P., Aguet M., Weissmann C., Mice devoid of PrP are resistant to scrapie, Cell (1993) 73:1339-1347.

[15] Burthem J., Urban B., Pain A., Roberts D.J., The normal cellular prion protein is strongly expressed by myeloid dendritic cells, Blood (2001) 98:3733-3738.

[16] Carleton A., Tremblay P., Vincent J.D., Lledo P.M., Dose-dependent, prion protein (PrP)-mediated facilitation of excitatory synaptic transmission in the mouse hippocampus, Pflugers Arch. (2001) 442:223229.

[17] Cashman N.R., Loertscher R., Nalbantoglu J., Shaw I., Kascsak R.J., Bolton D.C., Bendheim P.E., 
Cellular isoform of the scrapie agent protein participates in lymphocyte activation, Cell (1990) 61:185192.

[18] Chen Z., Lund R., Aittokallio T., Kosonen M., Nevalainen O., Lahesmaa R., Identification of novel IL-4/Stat6-regulated genes in T lymphocytes, J. Immunol. (2003) 171:3627-3635.

[19] Coitinho A.S., Roesler R., Martins V.R., Brentani R.R., Izquierdo I., Cellular prion protein ablation impairs behavior as a function of age, Neuroreport (2003) 14:1375-1379.

[20] Coitinho A.S., Freitas A.R., Lopes M.H., Hajj G.N., Roesler R., Walz R., Rossato J.I., Cammarota M., Izquierdo I., Martins V.R., Brentani R.R., The interaction between prion protein and laminin modulates memory consolidation, Eur. J. Neurosci. (2006) 24:3255-3264.

[21] Coitinho A.S., Lopes M.H., Hajj G.N., Rossato J.I., Freitas A.R., Castro C.C., Cammarota M., Brentani R.R., Izquierdo I., Martins V.R., Short-term memory formation and long-term memory consolidation are enhanced by cellular prion association to stress-inducible protein 1 , Neurobiol. Dis. (2007) 26:282-290.

[22] Colling S.B., Khana M., Collinge J., Jefferys J.G., Mossy fibre reorganization in the hippocampus of prion protein null mice, Brain Res. (1997) 755:28-35.

[23] Collinge J., Whittington M.A., Sidle K.C., Smith C.J., Palmer M.S., Clarke A.R., Jefferys J.G., Prion protein is necessary for normal synaptic function, Nature (1994) 370:295-297.

[24] Criado J.R., Sanchez-Alavez M., Conti B., Giacchino J.L., Wills D.N., Henriksen S.J., Race R., Manson J.C., Chesebro B., Oldstone M.B., Mice devoid of prion protein have cognitive deficits that are rescued by reconstitution of PrP in neurons, Neurobiol. Dis. (2005) 19:255-265.

[25] Crozet C., Vezilier J., Delfieu V., Nishimura T., Onodera T., Casanova D., Lehmann S., Beranger F., The truncated 23-230 form of the prion protein localizes to the nuclei of inducible cell lines independently of its nuclear localization signals and is not cytotoxic, Mol. Cell. Neurosci. (2006) 32:315-323.

[26] De Almeida C.J., Chiarini L.B., da Silva J.P., e Silva P.M., Martins M.A., Linden R., The cellular prion protein modulates phagocytosis and inflammatory response, J. Leukoc. Biol. (2005) 77:238-246.

[27] Dodelet V.C., Cashman N.R., Prion protein expression in human leukocyte differentiation, Blood (1998) 91:1556-1561.

[28] Durig J., Giese A., Schmucker U., Kretzschmar H.A., Duhrsen U., Decreased prion protein expression in human peripheral blood leucocytes from patients with paroxysmal nocturnal haemoglobinuria, $\mathrm{Br}$. J. Haematol. (2001) 112:658-662.
[29] Eaton S.L., Rocchi M., Gonzalez L., Hamilton S., Finlayson J., Sales J., Jeffrey M., Steele P.J., Dagleish M.P., Rodger S.M., Reid H.W., Chianini F., Immunological differences between susceptible and resistant sheep during the preclinical phase of scrapie infection, J. Gen. Virol. (2007) 88:1384-1391.

[30] Flechsig E., Hegyi I., Leimeroth R., Zuniga A., Rossi D., Cozzio A., Schwarz P., Rulicke T., Gotz J., Aguzzi A., Weissmann C., Expression of truncated PrP targeted to Purkinje cells of PrP knockout mice causes Purkinje cell death and ataxia, EMBO J. (2003) 22:3095-3101.

[31] Fontes P., Alvarez-Martinez M.T., Gross A., Carnaud C., Kohler S., Liautard J.P., Absence of evidence for the participation of the macrophage cellular prion protein in infection with Brucella suis, Infect. Immun. (2005) 73:6229-6236.

[32] Ford M.J., Burton L.J., Morris R.J., Hall S.M., Selective expression of prion protein in peripheral tissues of the adult mouse, Neuroscience (2002) 113:177-192.

[33] Fournier J.G., Escaig-Haye F., Grigoriev V., Ultrastructural localization of prion proteins: physiological and pathological implications, Microsc. Res. Tech. (2000) 50:76-88.

[34] Gauczynski S., Peyrin J.M., Haik S., Leucht C., Hundt C., Rieger R., Krasemann S., Deslys J.P., Dormont D., Lasmezas C.I., Weiss S., The $37-\mathrm{kDa} / 67-$ $\mathrm{kDa}$ laminin receptor acts as the cell-surface receptor for the cellular prion protein, EMBO J. (2001) 20:5863-5875.

[35] Golding M.C., Long C.R., Carmell M.A., Hannon G.J., Westhusin M.E., Suppression of prion protein in livestock by RNA interference, Proc. Natl. Acad. Sci. USA (2006) 103:5285-5290.

[36] Graner E., Mercadante A.F., Zanata S.M., Forlenza O.V., Cabral A.L., Veiga S.S., Juliano M.A., Roesler R., Walz R., Minetti A., Izquierdo I., Martins V.R., Brentani R.R., Cellular prion protein binds laminin and mediates neuritogenesis, Brain Res. Mol. Brain Res. (2000) 76:85-92.

[37] Grant S.G., O’Dell T.J., Karl K.A., Stein P.L., Soriano P., Kandel E.R., Impaired long-term potentiation, spatial learning, and hippocampal development in fyn mutant mice, Science (1992) 258:1903-1910.

[38] Hachiya N.S., Watanabe K., Sakasegawa Y., Kaneko K., Microtubules-associated intracellular localization of the NH2-terminal cellular prion protein fragment, Biochem. Biophys. Res. Commun. (2004) 313:818-823.

[39] Harris D.A., True H.L., New insights into prion structure and toxicity, Neuron (2006) 50:353-357.

[40] Harris E.D., Basic and clinical aspects of copper, Crit. Rev. Clin. Lab. Sci. (2003) 40:547-586.

[41] Herms J., Tings T., Gall S., Madlung A., Giese A., Siebert H., Schurmann P., Windl O., Brose N., 
Kretzschmar H., Evidence of presynaptic location and function of the prion protein, J. Neurosci. (1999) 19:8866-8875.

[42] Holada K., Vostal J.G., Different levels of prion protein $(\mathrm{PrPc})$ expression on hamster, mouse and human blood cells, Br. J. Haematol. (2000) 110:472-480.

[43] Horiuchi M., Yamazaki N., Ikeda T., Ishiguro N., Shinagawa M., A cellular form of prion protein (PrPC) exists in many non-neuronal tissues of sheep, J. Gen. Virol. (1995) 76:2583-2587.

[44] Hugel B., Martinez M.C., Kunzelmann C., Blattler T., Aguzzi A., Freyssinet J.M., Modulation of signal transduction through the cellular prion protein is linked to its incorporation in lipid rafts, Cell. Mol. Life Sci. (2004) 61:2998-3007.

[45] Kanaani J., Prusiner S.B., Diacovo J., Baekkeskov S., Legname G., Recombinant prion protein induces rapid polarization and development of synapses in embryonic rat hippocampal neurons in vitro, J. Neurochem. (2005) 95:1373-1386.

[46] Kim B.H., Lee H.G., Choi J.K., Kim J.I., Choi E.K., Carp R.I., Kim Y.S., The cellular prion protein (PrPC) prevents apoptotic neuronal cell death and mitochondrial dysfunction induced by serum deprivation, Brain Res. Mol. Brain Res. (2004) 124:40-50.

[47] Kurschner C., Morgan J.I., The cellular prion protein (PrP) selectively binds to Bcl-2 in the yeast two-hybrid system, Brain Res. Mol. Brain Res. (1995) 30:165-168.

[48] Kurschner C., Morgan J.I., Analysis of interaction sites in homo- and heteromeric complexes containing Bcl-2 family members and the cellular prion protein, Brain Res. Mol. Brain Res. (1996) 37:249-258.

[49] Kuwahara C., Takeuchi A.M., Nishimura T., Haraguchi K., Kubosaki A., Matsumoto Y., Saeki K., Matsumoto Y., Yokoyama T., Itohara S., Onodera T., Prions prevent neuronal cell-line death, Nature (1999) 400:225-226.

[50] Laine J., Marc M.E., Sy M.S., Axelrad H., Cellular and subcellular morphological localization of normal prion protein in rodent cerebellum, Eur. J. Neurosci. (2001) 14:47-56.

[51] Lee K.S., Linden R., Prado M.A., Brentani R.R., Martins V.R., Towards cellular receptors for prions, Rev. Med. Virol. (2003) 13:399-408.

[52] Lehmann S., Metal ions and prion diseases, Curr. Opin. Chem. Biol. (2002) 6:187-192.

[53] Li A., Harris D.A., Mammalian prion protein suppresses Bax-induced cell death in yeast, J. Biol. Chem. (2005) 280:17430-17434.

[54] Li R., Liu D., Zanusso G., Liu T., Fayen J.D., Huang J.H., Petersen R.B., Gambetti P., Sy M.S., The expression and potential function of cellular prion protein in human lymphocytes, Cell. Immunol. (2001) 207:49-58.
[55] Liu T., Li R., Wong B.S., Liu D., Pan T., Petersen R.B., Gambetti P., Sy M.S., Normal cellular prion protein is preferentially expressed on subpopulations of murine hemopoietic cells, J. Immunol. (2001) 166:3733-3742.

[56] Lopes M.H., Hajj G.N., Muras A.G., Mancini G.L., Castro R.M., Ribeiro K.C., Brentani R.R., Linden R., Martins V.R., Interaction of cellular prion and stress-inducible protein 1 promotes neuritogenesis and neuroprotection by distinct signaling pathways, J. Neurosci. (2005) 25:11330-11339.

[57] Ma J., Wollmann R., Lindquist S., Neurotoxicity and neurodegeneration when PrP accumulates in the cytosol, Science (2002) 298:1781-1785.

[58] Magalhaes A.C., Silva J.A., Lee K.S., Martins V.R., Prado V.F., Ferguson S.S., Gomez M.V., Brentani R.R., Prado M.A., Endocytic intermediates involved with the intracellular trafficking of a fluorescent cellular prion protein, J. Biol. Chem. (2002) 277:3331133318 .

[59] Mallucci G.R., Ratte S., Asante E.A., Linehan J., Gowland I., Jefferys J.G., Collinge J., Post-natal knock-out of prion protein alters hippocampal CA1 properties, but does not result in neurodegeneration, EMBO J. (2002) 21:202-210.

[60] Manson J.C., Clarke A.R., Hooper M.L., Aitchison L., McConnell I., Hope J., 129/Ola mice carrying a null mutation in PrP that abolishes mRNA production are developmentally normal, Mol. Neurobiol. (1994) 8:121-127.

[61] Martinez del Hoyo G., Lopez-Bravo M., Metharom P., Ardavin C., Aucouturier P., Prion protein expression by mouse dendritic cells is restricted to the nonplasmacytoid subsets and correlates with the maturation state, J. Immunol. (2006) 177:6137-6142.

[62] Martins V.R., Graner E., Garcia-Abreu J., de Souza S.J., Mercadante A.F., Veiga S.S., Zanata S.M., Neto V.M., Brentani R.R., Complementary hydropathy identifies a cellular prion protein receptor, Nat. Med. (1997) 3:1376-1382.

[63] Martins V.R., Brentani R.R., The biology of the cellular prion protein, Neurochem. Int. (2002) 41:353355 .

[64] Mazzoni I.E., Ledebur H.C. Jr, Paramithiotis E., Cashman N., Lymphoid signal transduction mechanisms linked to cellular prion protein, Biochem. Cell Biol. (2005) 83:644-653.

[65] McMahon H.E., Mange A., Nishida N., Creminon C., Casanova D., Lehmann S., Cleavage of the amino terminus of the prion protein by reactive oxygen species, J. Biol. Chem. (2001) 276:2286-2291.

[66] Mironov A. Jr, Latawiec D., Wille H., Bouzamondo-Bernstein E., Legname G., Williamson R.A., Burton D., DeArmond S.J., Prusiner S.B., Peters P.J., Cytosolic prion protein in neurons, J. Neurosci. (2003) 23:7183-7193. 
[67] Mouillet-Richard S., Laurendeau I., Vidaud M., Kellermann O., Laplanche J.L., Prion protein and neuronal differentiation: quantitative analysis of prnp gene expression in a murine inducible neuroectodermal progenitor, Microbes Infect. (1999) 1:969-976.

[68] Mouillet-Richard S., Ermonval M., Chebassier C., Laplanche J.L., Lehmann S., Launay J.M., Kellermann O., Signal transduction through prion protein, Science (2000) 289:1925-1928.

[69] Mouillet-Richard S., Schneider B., Pradines E., Pietri M., Ermonval M., Grassi J., Richards J.G., Mutel V., Launay J.M., Kellermann O., Cellular prion protein signaling in serotonergic neuronal cells, Ann. NY Acad. Sci. (2007) 1096:106-119.

[70] Moya K.L., Sales N., Hassig R., Creminon C., Grassi J., Di Giamberardino L., Immunolocalization of the cellular prion protein in normal brain, Microsc. Res. Tech. (2000) 50:58-65.

[71] Moya K.L., Hassig R., Creminon C., Laffont I., Di Giamberardino L., Enhanced detection and retrograde axonal transport of $\mathrm{PrPc}$ in peripheral nerve, $\mathrm{J}$. Neurochem. (2004) 88:155-160.

[72] Negro A., Ballarin C., Bertoli A., Massimino M.L., Sorgato M.C., The metabolism and imaging in live cells of the bovine prion protein in its native form or carrying single amino acid substitutions, Mol. Cell. Neurosci. (2001) 17:521-538.

[73] Nieznanski K., Podlubnaya Z.A., Nieznanska H., Prion protein inhibits microtubule assembly by inducing tubulin oligomerization, Biochem. Biophys. Res. Commun. (2006) 349:391-399.

[74] Paar C., Wurm S., Pfarr W., Sonnleitner A., Wechselberger C., Prion protein resides in membrane microclusters of the immunological synapse during lymphocyte activation, Eur. J. Cell Biol. (2007).

[75] Paisley D., Banks S., Selfridge J., McLennan N.F., Ritchie A.M., McEwan C., Irvine D.S., Saunders P.T., Manson J.C., Melton D.W., Male infertility and DNA damage in Doppel knockout and prion protein/Doppel double-knockout mice, Am. J. Pathol. (2004) 164:2279-2288.

[76] Paitel E., Alves da Costa C., Vilette D., Grassi J., Checler F., Overexpression of PrPc triggers caspase 3 activation: potentiation by proteasome inhibitors and blockade by anti-PrP antibodies, J. Neurochem. (2002) 83:1208-1214.

[77] Paitel E., Fahraeus R., Checler F., Cellular prion protein sensitizes neurons to apoptotic stimuli through Mdm2-regulated and p53-dependent caspase 3-like activation, J. Biol. Chem. (2003) 278:10061-10066.

[78] Paitel E., Sunyach C., Alves da Costa C., Bourdon J.C., Vincent B., Checler F., Primary cultured neurons devoid of cellular prion display lower responsiveness to staurosporine through the control of p53 at both transcriptional and post-transcriptional levels, J. Biol. Chem. (2004) 279:612-618.
[79] Papassotiropoulos A., Wollmer M.A., Aguzzi A., Hock C., Nitsch R.M., de Quervain D.J., The prion gene is associated with human long-term memory, Hum. Mol. Genet. (2005) 14:2241-2246.

[80] Petchanikow C., Saborio G.P., Anderes L., Frossard M.J., Olmedo M.I., Soto C., Biochemical and structural studies of the prion protein polymorphism, FEBS Lett. (2001) 509:451-456.

[81] Peters P.J., Mironov A. Jr, Peretz D., van Donselaar E., Leclerc E., Erpel S., DeArmond S.J., Burton D.R., Williamson R.A., Vey M., Prusiner S.B., Trafficking of prion proteins through a caveolaemediated endosomal pathway, J. Cell Biol. (2003) 162:703-717.

[82] Petrakis S., Sklaviadis T., Identification of proteins with high affinity for refolded and native PrPC, Proteomics (2006) 6:6476-6484.

[83] Politopoulou G., Seebach J.D., Schmugge M., Schwarz H.P., Aguzzi A., Age-related expression of the cellular prion protein in human peripheral blood leukocytes, Haematologica (2000) 85:580-587.

[84] Prusiner S.B., Novel proteinaceous infectious particles cause scrapie, Science (1982) 216:136-144.

[85] Prusiner S.B., Prions, Proc. Natl. Acad. Sci. USA (1998) 95:13363-13383.

[86] Richt J.A., Kasinathan P., Hamir A.N., Castilla J., Sathiyaseelan T., Vargas F., Sathiyaseelan J., Wu H., Matsushita H., Koster J., Kato S., Ishida I., Soto C., Robl J.M., Kuroiwa Y., Production of cattle lacking prion protein, Nat. Biotechnol. (2007) 25:132-138.

[87] Rieger R., Edenhofer F., Lasmezas C.I., Weiss S., The human $37-\mathrm{kDa}$ laminin receptor precursor interacts with the prion protein in eukaryotic cells, Nat. Med. (1997) 3:1383-1388.

[88] Rodolfo K., Hassig R., Moya K.L., Frobert Y., Grassi J., Di Giamberardino L., A novel cellular prion protein isoform present in rapid anterograde axonal transport, Neuroreport (1999) 10:3639-3644.

[89] Roucou X., LeBlanc A.C., Cellular prion protein neuroprotective function: implications in prion diseases, J. Mol. Med. (2005) 83:3-11.

[90] Sakudo A., Lee D.C., Saeki K., Nakamura Y., Inoue K., Matsumoto Y., Itohara S., Onodera T., Impairment of superoxide dismutase activation by $\mathrm{N}$-terminally truncated prion protein $(\mathrm{PrP})$ in $\mathrm{PrP}$ deficient neuronal cell line, Biochem. Biophys. Res. Commun. (2003) 308:660-667.

[91] Sales N., Rodolfo K., Hassig R., Faucheux B., Di Giamberardino L., Moya K.L., Cellular prion protein localization in rodent and primate brain, Eur. J. Neurosci. (1998) 10:2464-2471.

[92] Schenkein J., Montagna P., Self management of fatal familial insomnia. Part 1: what is FFI?, MedGenMed (2006) 8:65. 
[93] Schneider B., Mutel V., Pietri M., Ermonval M., Mouillet-Richard S., Kellermann O., NADPH oxidase and extracellular regulated kinases $1 / 2$ are targets of prion protein signaling in neuronal and nonneuronal cells, Proc. Natl. Acad. Sci. USA (2003) 100:1332613331.

[94] Shamsir M.S., Dalby A.R., One gene, two diseases and three conformations: molecular dynamics simulations of mutants of human prion protein at room temperature and elevated temperatures, Proteins (2005) 59:275-290.

[95] Shmerling D., Hegyi I., Fischer M., Blattler T., Brandner S., Gotz J., Rulicke T., Flechsig E., Cozzio A., von Mering C., Hangartner C., Aguzzi A., Weissmann C., Expression of amino-terminally truncated $\operatorname{PrP}$ in the mouse leading to ataxia and specific cerebellar lesions, Cell (1998) 93:203-214.

[96] Solforosi L., Criado J.R., McGavern D.B., Wirz S., Sanchez-Alavez M., Sugama S., DeGiorgio L.A., Volpe B.T., Wiseman E., Abalos G., Masliah E., Gilden D., Oldstone M.B., Conti B., Williamson R.A., Crosslinking cellular prion protein triggers neuronal apoptosis in vivo, Science (2004) 303:1514-1516.

[97] Spudich A., Frigg R., Kilic E., Kilic U., Oesch B., Raeber A., Bassetti C.L., Hermann D.M., Aggravation of ischemic brain injury by prion protein deficiency: role of ERK-1/-2 and STAT-1, Neurobiol. Dis. (2005) 20:442-449.

[98] Stahl N., Prusiner S.B., Prions and prion proteins, FASEB J. (1991) 5:2799-2807.

[99] Steele A.D., Emsley J.G., Ozdinler P.H., Lindquist S., Macklis J.D., Prion protein (PrPc) positively regulates neural precursor proliferation during developmental and adult mammalian neurogenesis, Proc. Natl. Acad. Sci. USA (2006) 103:3416-3421.

[100] Stuermer C.A., Langhorst M.F., Wiechers M.F., Legler D.F., Von Hanwehr S.H., Guse A.H., Plattner $\mathrm{H}$., PrPc capping in $\mathrm{T}$ cells promotes its association with the lipid raft proteins reggie-1 and reggie-2 and leads to signal transduction, FASEB J. (2004) 18:1731-1733.

[101] Sugaya M., Nakamura K., Watanabe T., Asahina A., Yasaka N., Koyama Y., Kusubata M., Ushiki Y., Kimura K., Morooka A., Irie S., Yokoyama T., Inoue K., Itohara S., Tamaki K., Expression of cellular prionrelated protein by murine Langerhans cells and keratinocytes, J. Dermatol. Sci. (2002) 28:126-134.

[102] Sunyach C., Jen A., Deng J., Fitzgerald K.T., Frobert Y., Grassi J., McCaffrey M.W., Morris R., The mechanism of internalization of glycosylphosphatidylinositol-anchored prion protein, EMBO J. (2003) 22:3591-3601.

[103] Taylor D.R., Hooper N.M., The prion protein and lipid rafts, Mol. Membr. Biol. (2006) 23:89-99.

[104] Tobler I., Gaus S.E., Deboer T., Achermann P., Fischer M., Rulicke T., Moser M., Oesch B., McBride
P.A., Manson J.C., Altered circadian activity rhythms and sleep in mice devoid of prion protein, Nature (1996) 380:639-642.

[105] Vassallo N., Herms J., Behrens C., Krebs B., Saeki K., Onodera T., Windl O., Kretzschmar H.A., Activation of phosphatidylinositol 3-kinase by cellular prion protein and its role in cell survival, Biochem. Biophys. Res. Commun. (2005) 332:75-82.

[106] Vey M., Pilkuhn S., Wille H., Nixon R., DeArmond S.J., Smart E.J., Anderson R.G., Taraboulos A., Prusiner S.B., Subcellular colocalization of the cellular and scrapie prion proteins in caveolae-like membranous domains, Proc. Natl. Acad. Sci. USA (1996) 93:14945-14949.

[107] Watarai M., Kim S., Erdenebaatar J., Makino S., Horiuchi M., Shirahata T., Sakaguchi S., Katamine S., Cellular prion protein promotes Brucella infection into macrophages, J. Exp. Med. (2003) 198:5-17.

[108] Watt N.T., Taylor D.R., Gillott A., Thomas D.A., Perera W.S., Hooper N.M., Reactive oxygen speciesmediated beta-cleavage of the prion protein in the cellular response to oxidative stress, J. Biol. Chem. (2005) 280:35914-35921

[109] Weise J., Crome O., Sandau R., Schulz-Schaeffer W., Bahr M., Zerr I., Upregulation of cellular prion protein $(\mathrm{PrPc})$ after focal cerebral ischemia and influence of lesion severity, Neurosci. Lett. (2004) 372:146-150.

[110] Weise J., Sandau R., Schwarting S., Crome O., Wrede A., Schulz-Schaeffer W., Zerr I., Bahr M., Deletion of cellular prion protein results in reduced Akt activation, enhanced postischemic caspase-3 activation, and exacerbation of ischemic brain injury, Stroke (2006) 37:1296-1300.

[111] Weissmann C., Flechsig E., PrP knock-out and PrP transgenic mice in prion research, Br. Med. Bull. (2003) 66:43-60.

[112] Wells M.A., Jackson G.S., Jones S., Hosszu L.L., Craven C.J., Clarke A.R., Collinge J., Waltho J.P., A reassessment of copper(II) binding in the full-length prion protein, Biochem. J. (2006) 399:435-444.

[113] Westergard L., Christensen H.M., Harris D.A., The cellular prion protein $(\operatorname{PrP}(C))$ : its physiological function and role in disease, Biochim. Biophys. Acta (2007) 1772:629-644.

[114] Zanata S.M., Lopes M.H., Mercadante A.F., Hajj G.N., Chiarini L.B., Nomizo R., Freitas A.R., Cabral A.L., Lee K.S., Juliano M.A., de Oliveira E., Jachieri S.G., Burlingame A., Huang L., Linden R., Brentani R.R., Martins V.R., Stress-inducible protein 1 is a cell surface ligand for cellular prion that triggers neuroprotection, EMBO J. (2002) 21:3307-3316.

[115] Zhang C.C., Steele A.D., Lindquist S., Lodish H.F., Prion protein is expressed on long-term repopulating hematopoietic stem cells and is important for their self-renewal, Proc. Natl. Acad. Sci. USA (2006) 103:2184-2189. 